\title{
Divulgação da Carta Ilustrada Sobre Os Direitos dos Usuários da Saúde em Rodas de Conversa: Relato de Experiência
}

\author{
Silva, Elzicléa de Oliveira; Santos, Valci Melo Silva dos; Silva, Ana Clarisse Freire da \\ Secretaria Municipal de Saúde do Município de Senador Rui Palmeira/Al — elz.oliveira@gmail.com
}

INTRODUÇÃO - Levando em consideração o artigo 196 da Constituição de 1988, onde refere que, "a saúde é direito de todos e dever do Estado, garantido mediante políticas sociais e econômicas que visem à redução do risco de doença e de outros agravos e ao acesso universal e igualitário às ações e serviços para sua promoção, proteção e recuperação", tornase interessante que os usuários do Sistema Único de Saúde (SUS) passem a conhecer os direitos que lhe cabem para que possam reivindicá-los. para isso, o Conselho Nacional de Saúde (CNS), em 2009 legitimou em carta os Direitos dos Usuários da Saúde, com pilares em seis princípios, que envolvem direito ao serviço de saúde, ao tratamento adequado, ao acolhimento e humanização em seu atendimento (BRASIL, 2011), reforçando a ideia de acessibilidade universal e igualitária em um serviço de qualidade. OBJETIVOS - o presente trabalho tem o objetivo de relatar uma experiência do Conselho Municipal de Saúde, e dos profissionais da área de saúde, de um determinado município do interior de Alagoas tendo em vista a divulgação dos direitos dos usuários através de rodas de conversa, panfletagem e exposição em banner da versão ilustrada da carta de Direitos dos Usuários da Saúde, nas Unidades Básicas de Saúde. MÉTODOS - Trata-se de um relato descritivo de uma experiência do Conselho Municipal de Saúde, e dos profissionais da área de saúde sobre a divulgação dos direitos dos Usuários da Saúde, a partir de rodas de conversas, panfletagem e exposição em banner ilustrado sobre a temática, acontecidas durante o ano de 2012. para isso, foi montado a seguinte estratégia: 1. Confeccionar em banner a carta ilustrada sobre os direitos dos usuários à saúde; 2 . Montar e divulgar um cronograma quinzenal de visitas à comunidade; 3. Difundir entre as outras Equipes de Saúde a importância do usuário conhecer seus direitos. RESULTADOS - de acordo com as observações foi constatado que os usuários da saúde não conheciam seus direitos, devido a uma grande parcela dos mesmos não ser alfabetizada. Dessa maneira, a carta ilustrada surgiu como uma ferramenta capaz de chamar a atenção, proporcionando maior acessibilidade aos usuários. CONCLUSÕES - Acreditamos que a nossa experiência torna-se válida, já que passamos a promover conhecimento à comunidade que poderá transformar e gerar mais saberes, estabelecendo mais uma opção de reivindicar uma assistência universal, integral e equânime, a partir do conhecimento adquirido. REFERÊNCIAS BRASIL. Ministério da Saúde. Carta dos direitos dos usuários da saúde. 3. ed. Brasília: Ministério da Saúde, 2011. ÍNDICE FUNDAMENTAL de DIREITO. Constituição $\quad$ Federal $1988 . \quad$ Disponível em: < http://www.dji.com.br/constituicao_federal/cf196a200.htm>. Acesso em: 23 jan 2013>

Silva, Elzicléa de Oliveira; Santos, Valci Melo Silva dos; Silva, Ana Clarisse Freire da. Divulgação da Carta Ilustrada Sobre Os Direitos dos Usuários da Saúde em Rodas de Conversa: Relato de Experiência. In: Anais do Congresso Internacional de Humanidades \& Humanização em Saúde [= Blucher Medical Proceedings, num.2, vol.1]. São Paulo: Editora Blucher, 2014. ISSN 2357-7282

DOI 10.5151/medpro-cihhs-10548 